\title{
1 Glassy aerosol may promote virus transmission
}

2 Robert Groth ${ }^{1}$, Sadegh Niazi ${ }^{1}$, Graham R. Johnson ${ }^{1}$, and Zoran Ristovski ${ }^{1}$

$3{ }^{1}$ International Laboratory for Air Quality and Health (ILAQH), School of Earth and Atmospheric Sciences, Queensland

4 University of Technology, Brisbane, Australia

5

$6 \quad$ Corresponding author: z.ristovski@qut.edu.au

\section{Abstract}

8 The impact of respiratory particle composition on the equilibrium morphology and phase are not well understood. Furthermore, the effects of these different phases and morphologies on the viability of viruses embedded within these particles are equally unknown. Physiologically relevant respiratory fluid analogues were constructed, and their hygroscopic behavior were measured using an ensemble technique. A relationship between hygroscopicity and protein concentration was determined, providing additional validation to the high protein content of respiratory aerosol measured in prior works (>90\%). Atomic force microscopy was used to probe the viscoelasticity of deposited protein particles, and transmission electron microscopy was used to observe the morphology of dried composite protein/salt particles. It was found that dried protein particles at indoor-relevant climatic conditions could exist separately in a glassy or viscous semisolid state. A glassy protein shell could kinetically 'freeze' a particle at conditions more favorable for virus viability.

Keywords respiratory aerosol, droplet physicochemistry, virus viability, glassy aerosol, hygroscopic growth, atomic force microscopy, transmission electron microscopy

\section{Introduction}

The emergence of the severe acute respiratory syndrome coronavirus 2 (SARS-CoV-2) pandemic has brought increased attention to the airborne transmission of viruses. There is evidence that the transmission of SARS-CoV-2, among other prominent respiratory viruses such as influenza and rhinovirus, can be through the airborne mode ${ }^{1-3}$. Recent research has solidified the importance of the airborne route and have highlighted the gaps in knowledge regarding this process ${ }^{3-5}$. Most importantly, the link between droplet physicochemistry and virus viability and transport are not well understood and yet are crucial for managing and preventing transmission. In measurements of airborne virus viability, climatic conditions, particularly absolute or relative humidity $(\mathrm{RH})$ and temperature, have shown to be important factors in contribution to virus viability ${ }^{6-12}$. This is likely 
due to physical and chemical interactions between the ambient air and the particle in which the viruses are embedded ${ }^{13}$.

Viruses emitted into the air through expiration (talking, breathing, coughing, sneezing, etc.) will be embedded in droplets composed of the fluid which lines the respiratory tract ${ }^{14-16}$. The solutes in this respiratory fluid will interact with the atmosphere and provide the microenvironment for the viruses. The exact composition of the respiratory fluid will vary by production region and also between individuals. The primary composition of respiratory fluid is proteins, inorganic salts and surfactants ${ }^{17-19}$. Simulating respiratory fluid for use in virus experiments is not trivial, as respiratory fluid is a viscoelastic fluid (e.g., mucus) and is not easily nebulized. The protein content of human respiratory aerosol is estimated to be upwards of $90 \%$ by solute total volume ${ }^{20}$. The primary inorganic is $\mathrm{NaCl}$, which is a hygroscopic salt, and therefore human respiratory aerosol exhibits hygroscopic growth ${ }^{20}$. In the context of airborne virus transmission, this means that as the droplets are released into the atmosphere, they will release water to reach equilibrium with ambient RH. Additionally, the respiratory particles may exhibit RH-dependent discontinuous phase transitions depending on composition ${ }^{20}$. Upon dehydration, aqueous $\mathrm{NaCl}$ particles will promptly release the remaining liquid water and crystallize (effloresce) below the efflorescence (ERH, 45\% RH). Conversely, upon subsequent hydration, crystalline $\mathrm{NaCl}$ particles will uptake water vapor until prompt redissolution (deliquescence) at the deliquescence RH (DRH, 75\% RH). Deliquescence and efflorescence have also been observed in human respiratory aerosol, indicating that the phase state of the particles may have further influence on the viability of airborne viruses ${ }^{20}$.

Studying the dynamics and viability of airborne viruses has been of importance in determining the transmission route of viral respiratory infections. Studies have been conducted on both infectious

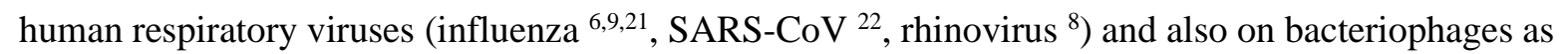
viral surrogates (bacteriophage phi6 ${ }^{23,24}, \mathrm{MS} 2{ }^{24,25}$ ). The results of these studies suggest complex mechanisms determine the viability of the virus, with a 'V-shape' $\mathrm{RH}$ dependence being a common occurrence. Increased fractions of viable viruses are observed at high and low RH and viability is typically minimised at intermediate $\mathrm{RH}$.

Effects of particle composition, morphology and phase state on virus viability are not well understood, although it is clear that they are important. Phase transitions of hygroscopic salts may explain parts of the $\mathrm{V}$-shaped viability curve, and equilibria such as liquid-liquid phase separation (LLPS) may explain the increase inactivation at intermediate RH. Semisolid phases, such as glassy or high viscosity semisolids, may also influence virus viability at indoor-relevant $\mathrm{RH}^{26-29}$. Glassy aerosol are extremely viscous semisolid particles and have bulk properties like solids (hardness, rigidity) and inhibit molecular diffusion. The occurrence of these phenomena, of course, depend primarily on the interactions between the particle solutes and the ambient atmosphere. If the primary 
mechanism of virus inactivation in respiratory particles is through exposure to highly ionic solutions, such as concentrated aqueous salts, then it becomes clear that higher protein concentration particles would favor virus viability. Therefore, in laboratory studies of virus viability, it becomes most prudent to ensure that the composition of the nebulization fluid is representative of typical respiratory aerosol. Studies have aimed to use simulated respiratory fluid (SRF) to investigate aerosol dynamics and virus viability ${ }^{8,9,24,30-32}$. In all cases, the primary components of the $\mathrm{SRF}$ were $\mathrm{NaCl}$ and protein (combinations of mucins and albumins). It has been demonstrated that the composition of human respiratory aerosol can be primarily proteins ( $>90 \%$ by volume) and may be useful in future works to incorporate larger protein concentrations ${ }^{20,29}$.

In this work, we investigate the effects of protein concentration on the morphology and phase state of simulated respiratory particles. We use different particle protein volume fractions and used an ensemble technique to measure the average hygroscopic behavior of the particles at different $\mathrm{RH}$ values ${ }^{20,33-35}$. We collected particles for transmission electron microscopy (TEM) and atomic force microscopy (AFM) analysis to determine morphology and viscoelastic properties of the particles. Previous methods ${ }^{36}$ were adapted to produce a phase diagram of SRF aerosol as a function of RH, which predicts glassy solid phase of respiratory aerosol. The recent work of Huynh et al. is supported in this work, identifying semisolid phases of SRF ${ }^{29}$. Particularly, evidence of distinct viscoelastic semisolid phases of porcine gastric mucin were observed, varying between glassy and moderately viscous. The influence of particle phase and morphology on virus viability are not well understood, but the work here provides some foundation for future studies.

\section{Experimental section}

\subsection{Sample preparation}

The bulk simulated respiratory fluid (SRF) mixtures used in this study were composed of water, porcine gastric mucin (PGM) (type III, Sigma-Aldrich) and $\mathrm{NaCl}$ (>99\%, Sigma-Aldrich). PGM was used as an analogue for human respiratory mucin, as mucin $5 \mathrm{AC}$ are primary mucins present in both human airways and in the gastrointestinal tract of pigs ${ }^{37,38}$. Each mixture was prepared with a predetermined target organic mass fraction of dry solutes $\left(w_{0}\right)$. The mass of the dry solutes were measured in separate vials and then added to $40 \mathrm{~mL}$ of $18.2 \mathrm{M} \Omega \cdot \mathrm{cm}$ water (Milli-Q). The final mass of the vials were then measured to calculate the organic volume fraction of dry solutes $\left(\phi_{0}\right)$ in each mixture (Table 1). The aerosol were generated using a Collison nebulizer with filtered and dried compressed air as the carrier gas.

\begin{tabular}{|l|c|}
\hline$w_{0}$ & $\phi_{0}$ \\
\hline
\end{tabular}




\begin{tabular}{|c|c|}
\hline $0.238 \pm 0.004$ & $0.385 \pm 0.01$ \\
\hline $0.538 \pm 0.005$ & $0.700 \pm 0.01$ \\
\hline $0.666 \pm 0.007$ & $0.800 \pm 0.02$ \\
\hline $0.741 \pm 0.007$ & $0.851 \pm 0.02$ \\
\hline $0.811 \pm 0.01$ & $0.896 \pm 0.02$ \\
\hline $0.905 \pm 0.02$ & $0.950 \pm 0.05$ \\
\hline $0.912 \pm 0.02$ & $0.954 \pm 0.05$ \\
\hline $0.934 \pm 0.03$ & $0.966 \pm 0.06$ \\
\hline 1 & 1 \\
\hline
\end{tabular}

Table 1. The measured organic mass fraction of dry solutes $\left(w_{O}\right)$ and organic volume fraction of dry solutes $\left(\phi_{O}\right)$ in each simulated respiratory fluid solution.

Additionally, solutions of malonic acid (99\%, Sigma-Aldrich) and sucrose (>99.5\%, Sigma-Aldrich), were used for force-response atomic force microscopy (AFM) analysis as representative of liquid and semisolid states.

\subsection{Hygroscopic growth measurements}

The aerosol were passed through a silica diffusion dryer with an internal mesh (inner diameter $=2.5$ $\mathrm{cm}$ ) at $0.3 \mathrm{Lmin}^{-1}$ for a total length of $80 \mathrm{~cm}$ (residence time $\sim 80 \mathrm{~s}$ ). The relative humidity (RH) after drying the particles was measured using a RH sensor (HC2-C04, Rotronic AG, Switzerland) to be < $3 \%$. After being charge neutralized using a ${ }^{85} \mathrm{Kr}$ neutralizer, a monodisperse aerosol fraction at 100 $\mathrm{nm}$ was sampled from the original polydisperse sample with the first differential mobility analyser (DMA) (DMA1). The particles were then passed into a humidification tandem differential mobility analyser (H-TDMA), which is described in detail elsewhere ${ }^{20,33,34,39}$, and the diametric hygroscopic growth factors (GF) were measured for both hydration and dehydration humidity cycles. For hydration measurements (deliquescence), the monodisperse aerosol fraction was passed directly from the DMA1 outlet into the RH conditioning flow in the second DMA (DMA2). For dehydration measurements (efflorescence), the monodisperse aerosol fraction was pre-humidified ( $\mathrm{RH}>90 \%$ ) using a gas exchange cell (FC100-6, Perma Pure LLC, Lakewood, NJ) before entering the RH conditioning flow in DMA2. The sheath flow rate in DMA1 was $4.5 \mathrm{Lmin}^{-1}$ and the sheath flow rate in DMA2 was 3.5 $\mathrm{Lmin}^{-1}$ using mass flow controllers (MCP, Alicat Scientific, Inc., Tucson, AZ), and particle counts were measured after DMA2 using a TSI 3776 CPC (TSI, Shoreview, MN). The data were then inverted using the TDMAinv algorithm to calculate the diametric hygroscopic growth factor as the ratio of the diameter of the particles at some RH to the diameter of the particles at $\mathrm{RH}<$ $10 \%\left(\mathrm{GF}=\frac{D_{R H}}{D_{d r y}}\right)^{40}$. This process was repeated for each solution $w_{\mathrm{O}}$ listed in Table 1. 


\subsection{Atomic force microscopy}

127 Aerosol samples were collected for AFM analysis on Si chip wafers (Ted Pella, Inc.), which were first cleaned with ethanol and dried using nitrogen gas. Particles were collected onto the Si chips via electrostatic precipitation using a TSI Nanometer Aerosol Sampler 3089 (TSI, Shoreview, MN) operating at $-9 \mathrm{kV}$ with a flow rate of $1 \mathrm{Lmin}^{-1}$. Topographical images and force spectroscopy measurements were collected using a Bruker Dimension Icon PT AFM (Bruker Co., Billerica, MA). The AFM was housed in a vibration isolation chamber, in which the RH was measured to be $35 \pm 2 \%$ over the duration of the measurements. Silicon nitride probes with nominal spring constant of $0.4 \mathrm{Nm}^{-}$ measurement using the thermal noise method. Topographic images were collected in PeakForce Tapping mode, and force-response measurements were collected using the force ramp function in PeakForce QNM mode with a force threshold of $10 \mathrm{nN}$. As the tip was indented into the particles, the tip-particle separation distance and force recorded and used to infer viscoelastic properties of the particles ${ }^{41,42}$. The phase of the particles could then be determined as compared to phases of reference materials $(\mathrm{NaCl}$, sucrose, malonic acid).

\subsection{Transmission electron microscopy and energy-dispersive X-ray spectroscopy}

Aerosol samples were collected for transmission electron microscopy (TEM) analysis on either lacey carbon-coated copper (300 mesh, Ted Pella, Inc.) or continuous carbon-coated copper grids (200 mesh, Ted Pella, Inc.). Particles were collected onto the grids via electrostatic precipitation using a TSI Nanometer Aerosol Sampler 3089 (TSI, Shoreview, MN) operating at $-9 \mathrm{kV}$ with a flow rate of 1 $\mathrm{Lmin}^{-1}$. Electron micrographs were collected using a JEOL 2100 TEM with an accelerating voltage of $200 \mathrm{kV}$. Elemental analysis of the particles was performed using energy-dispersive X-ray spectroscopy (EDS) using an Oxford Instruments X-Max EDS detector (Oxford Instruments, Oxford, UK), which detects characteristic X-rays emitted from electron excitation during TEM measurement.

\section{Results and discussion}

\subsection{Hygroscopicity}

The hygroscopic growth factor (GF) of each mixture described in Table 1 are shown in Figure 1 as a function of relative humidity (RH). A measured sample of pure porcine gastric mucin (PGM) hygroscopic growth shows continuous water transfer with no evidence of discontinuous phase transitions. Additionally, a polynomial was also fit to the pure PGM data (Figure 1i) and is further discussed in the supplementary material (section S2) to predict diametric hygroscopic growth factor as a function of $\mathrm{RH}$. 
(a)

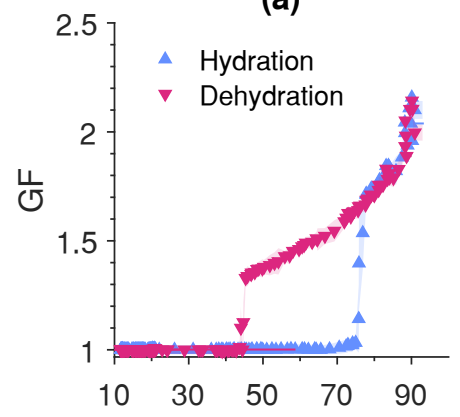

(d)

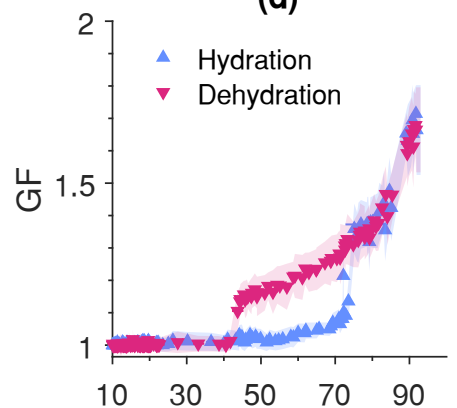

(g)

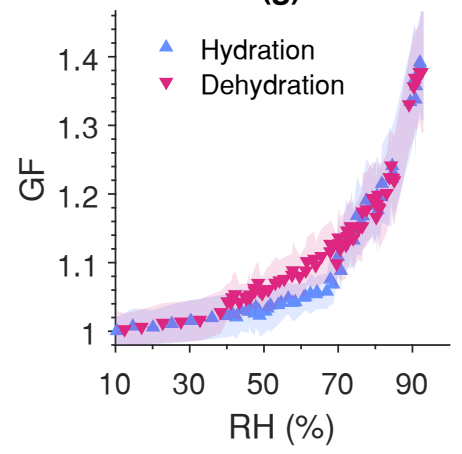

(b)

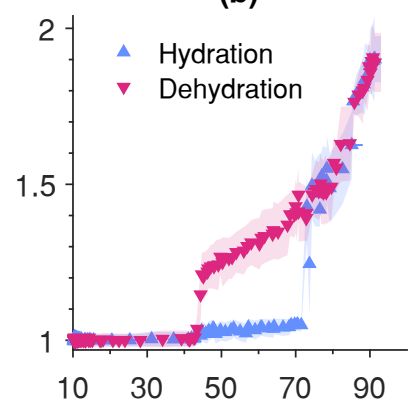

(e)

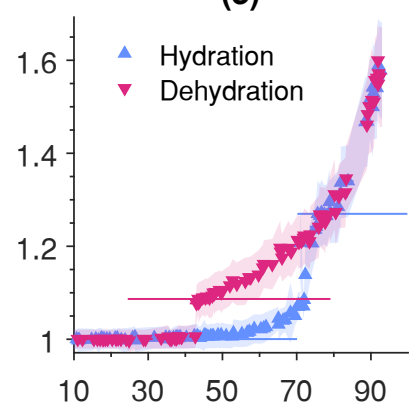

(h)

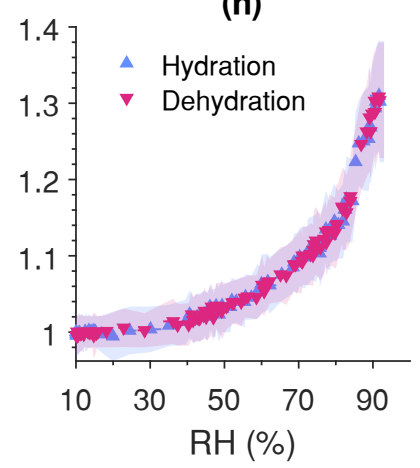

(c)

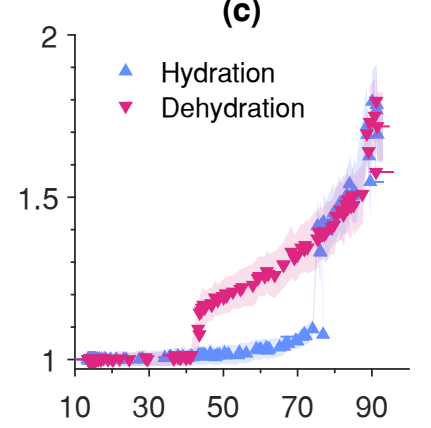

(f)

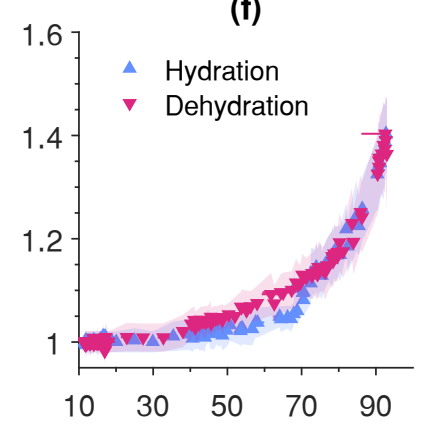

(i)

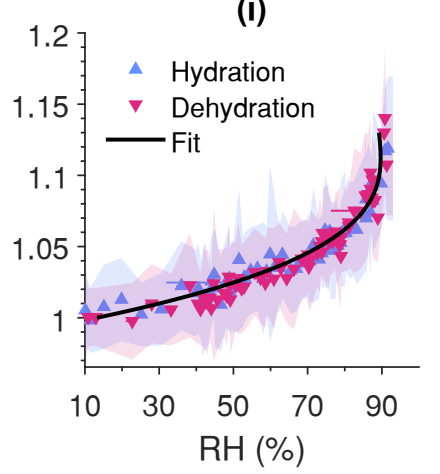

160

161 Figure 1. Hygroscopic growth factor $(G F)$ of simulated respiratory fluid particles as a function of relative humidity (RH) for

162 (a) 38\%, (b) 70\%), (c) 80\%, (d) 85\%, (e) 90\%, (f) 95, (g) 95.4\%, (h) 97\%, and (i) 100\% porcine gastric mucin by dry solute

163 volume. Discontinuities in the growth indicate liquid $\rightleftarrows$ solid phase transitions.

164 Table 2 shows the data from each different solution composition measured in this study. These results

165 show that as the mass of PGM in each sample increases, the GF at $90 \% \mathrm{RH}\left(\mathrm{GF}_{90}\right)$ for each sample

166 decreases, and that the midpoint-RH of efflorescence $\left(\mathrm{ERH}_{50}\right)$ decreases. A third-order polynomial

167 (equation (S9)) was fit to the experimental $\mathrm{GF}_{90}$ data (coefficients in Table S3) as a function of

168 organic volume fraction of dry solute $\left(\phi_{0}\right)$.

\begin{tabular}{|c|c|c|}
\hline$\phi_{0}$ & $\mathrm{GF}_{90}$ & $\mathrm{ERH}_{50}(\%)$ \\
\hline $0.38 \pm 0.01$ & $2.09 \pm 0.06$ & $44.9 \pm 0.4$ \\
\hline
\end{tabular}




\begin{tabular}{|c|c|c|}
\hline $0.70 \pm 0.01$ & $1.88 \pm 0.02$ & $44 \pm 0.8$ \\
\hline $0.80 \pm 0.02$ & $1.75 \pm 0.1$ & $43.2 \pm 1$ \\
\hline $0.85 \pm 0.02$ & $1.63 \pm 0.02$ & $43.1 \pm 1.5$ \\
\hline $0.90 \pm 0.02$ & $1.51 \pm 0.02$ & $42.9 \pm 0.2$ \\
\hline $0.95 \pm 0.05$ & $1.3 \pm 0.01$ & $38.1 \pm 1.8$ \\
\hline $0.954 \pm 0.05$ & $1.35 \pm 0.01$ & $38.7 \pm 1.4$ \\
\hline $0.97 \pm 0.06$ & $1.28 \pm 0.01$ & - \\
\hline 1 & $1.1 \pm 0.02$ & - \\
\hline 1 & $1.12 \pm 0.02$ & - \\
\hline
\end{tabular}

Table 2. Organic volume fraction of dry solutes $\left(\phi_{O}\right)$ of the simulated respiratory fluid solutions and their corresponding

171 hygroscopic growth factor at 90\% RH (GF90) and midpoint-efflorescence RH (ERH50). Efflorescence was not observed at $\phi_{0}>0.954$.

174 The efflorescence of particles of varying protein concentrations were determined using the

175 dehydration hygroscopic growth measurements. The process to determine $\mathrm{ERH}_{50}$ is explained in 176 greater detail in the supplementary material (section S3), but in short, four piecewise linear equations 177 were fit to each dehydration dataset between $30 \%<\mathrm{RH}<60 \%$. In all solution systems, this was 178 sufficient to clearly identify the onset and offset of efflorescence, if it existed. The $\mathrm{ERH}_{50}$ was then 179 calculated as the midpoint between the onset and offset of efflorescence and is visualised as a function 180 of organic volume fraction of dry solutes $\left(\phi_{\mathrm{O}}\right)$ in Figure 2. 


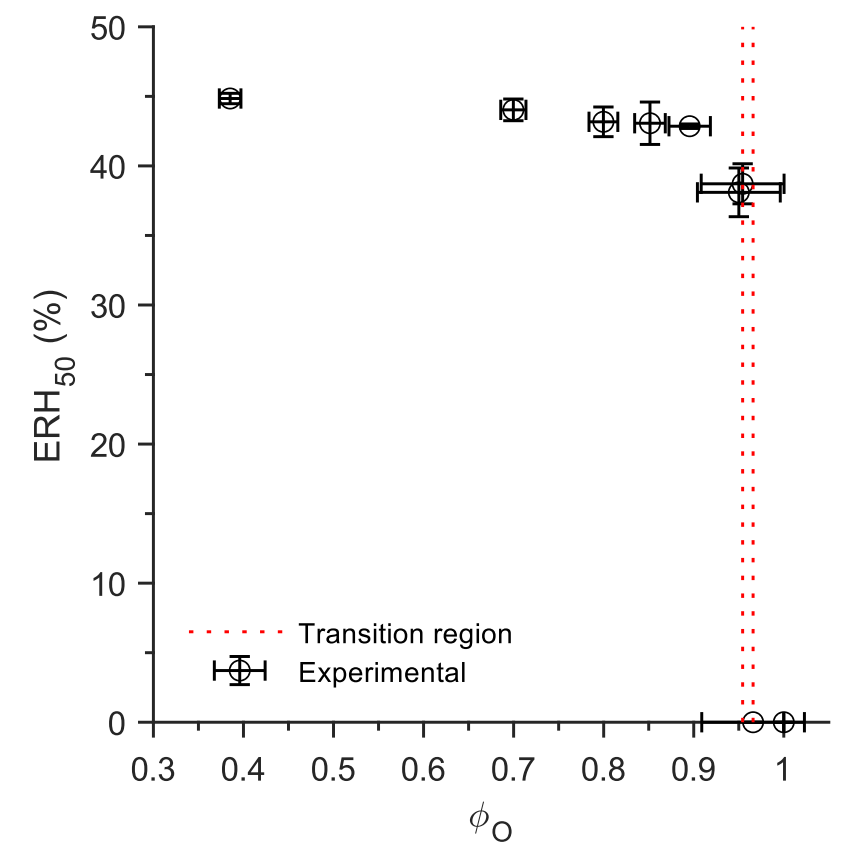

182 Figure 2. Midpoint-efflorescence relative humidity (ERH50) of simulated respiratory fluid aerosols as a function of organic

183 volume fraction of dry solutes $\left(\phi_{O}\right)$. The transition between efflorescing and non-efflorescing particles was observed

184 between $0.955<\phi_{0}<0.97$.

185 In this case, the ERH gradually decreases with increasing $\phi_{0}$ until it can no longer be distinctly 186 observed between $0.955<\phi_{0}<0.97$. A similar set of measurements using a solution composed of 187 bovine serum albumin (BSA) and $\mathrm{NaCl}$ was performed by Mikhailov et al. and identified a similar 188 trend, with efflorescence being suppressed at high $\phi_{\mathrm{O}}{ }^{43}$.

189 The $\mathrm{GF}_{90}$ values were calculated from experimental data by fitting a linear model to the GF values 190 between $89.5 \%$ and $90.5 \% \mathrm{RH}$ then and using the function input of $90 \% \mathrm{RH}$ to calculate the output $191 \mathrm{GF}_{90}$. Additionally, a physical model (separate solute volume-additivity, SS-VA ${ }^{43}$ ) and a simplified 192 mixing rule (Zdanovskii-Stokes-Robinson, $\mathrm{ZSR}^{44}$ ) were computed at $90 \% \mathrm{RH}$ for comparison (Figure 193 3a). 
(a)

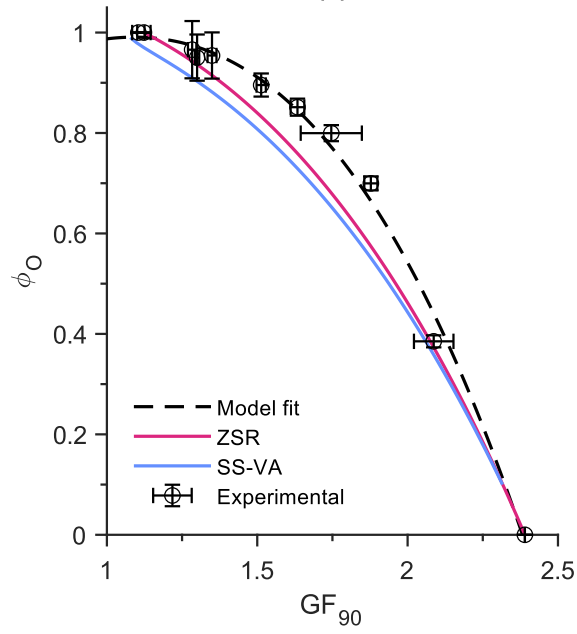

(b)

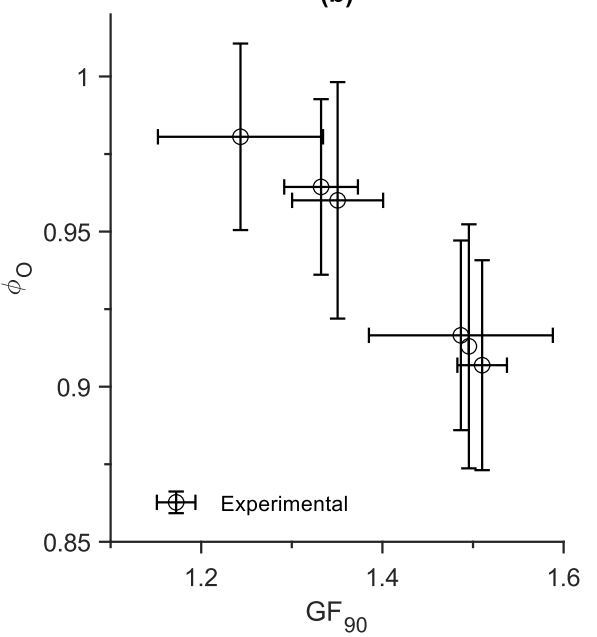

195

Figure 3. Organic volume fraction of dry solutes $\left(\phi_{0}\right)$ as a function of particle growth factor at $90 \%$ RH $\left(G F_{90}\right)$ for (a) simulated respiratory fluid solutions of known composition and (b) fitted to prior measured values of human respiratory aerosol as reported in Groth et al. ${ }^{20}$. A physical model (separate solute volume-additivity, SS-VA) and a simple mixing rule (Zdanovskii-Stokes-Robinson, ZSR) are shown as comparison to measured values.

The method to predict $\phi_{0}$ from $\mathrm{GF}_{90}$ can be extended to previous measurements of human respiratory aerosol hygroscopicity ${ }^{20}$. The $\mathrm{GF}_{90}$ of human participants and bovine bronchoalveolar lavage fluid (B-BALF) discussed in Groth et al. were then used to estimate $\phi_{\mathrm{O}}$ using equation (S9) (Figure 3b, Table S4). Using the $\mathrm{GF}_{90}$ to predict $\phi_{0}$ estimates that the organic volume fraction of the measured human respiratory aerosol is no less than $91 \%$. As discussed in the supplementary material (section S1), the physical models appear to underpredict the hygroscopicity of PGM, and thus, underpredict the organic volume fraction of the ternary particles. In our prior study, one participant and the BBALF exhibited the most distinct deliquescence and efflorescence. In comparison to those results, here we measured the hygroscopic behavior of a solution which was composed of 90\% PGM by volume, which also exhibited the state hysteresis behavior. Additionally, the next highest organic volume fraction measured in the human samples was $96.01 \%$ and does not exhibit efflorescence, consistent with the results of this study (Table S4). This indicates that the threshold for distinct efflorescence may be approximately $96 \%$ dry solute organic volume fraction.

\subsection{Simulated respiratory aerosol phase state}

The glass transition temperature ( $\mathrm{T}_{\mathrm{g}}$ ) of bulk PGM was measure using sorption calorimetry and differential scanning calorimetry (DSC) by Znamenskaya et al., and was reported as a function of weight $\%$ of PGM compared to water, and is discussed in greater detail in the supplementary material (section S4) ${ }^{36}$. Using the hygroscopic growth of PGM measured here (Figure 1), the weight $\%$ of

$$
\text { PGM in the aerosol can be calculated, and the } \mathrm{T}_{\mathrm{g}} \text { of PGM aerosol can be reported in terms of RH }
$$
(Figure 4a). This is a more useful interpretation of to predict the phase state of airborne particles in 
221 ambient conditions. Figure 4 shows predicted $\mathrm{T}_{\mathrm{g}}$ of PGM particles as a function of RH, and includes 222 the assumed particle phase state and morphology in each case. For pure PGM aerosol, Figure 4a 223 shows a region of elastic/gelated particles at $\mathrm{T}>\mathrm{T}_{\mathrm{g}}$ and glassy solid particles at $\mathrm{T}<\mathrm{T}_{\mathrm{g}}$. A gel is a

224 viscoelastic semisolid (deformable, soft), while a glass is a viscous semisolid (rigid, hard). Figure 4b 225 shows the case where the particles also contain $\mathrm{NaCl}$ but do not effloresce $\left(\phi_{0}=0.97\right)$ and shows 226 comparative behavior to Figure $4 \mathrm{a}$. For the case where $\mathrm{NaCl}$ is present in the system and at high 227 enough concentrations to exhibit efflorescence $\left(\phi_{O}=0.95\right)$, the particles exhibit an elastic/gelated 228 phase state at $\mathrm{T}>\mathrm{T}_{\mathrm{g}}$ and $\mathrm{RH}>\mathrm{ERH}$, a viscous/glassy phase state at $\mathrm{T}<\mathrm{T}_{\mathrm{g}}$ and $\mathrm{RH}>\mathrm{ERH}$, a gel-coated 229 crystalline core at $\mathrm{T}>\mathrm{T}_{\mathrm{g}}$ and $\mathrm{RH}<\mathrm{ERH}$, and a glassy-shell-coated crystalline core at $\mathrm{T}<\mathrm{T}_{\mathrm{g}}$ and $230 \mathrm{RH}<\mathrm{ERH}$ (Figure 4c). Generally, for a pure PGM, above $\mathrm{T}_{\mathrm{g}}$ the protein will be a gel-like semisolid 231 and below $\mathrm{T}_{\mathrm{g}}$ the protein will be a glass-like semisolid. If salts are present, above the ERH the 
particles will have an aqueous core and below the ERH the particles will have a crystalline core.

233 These four-phase systems are shown most clearly in Figure 4c.

(a)

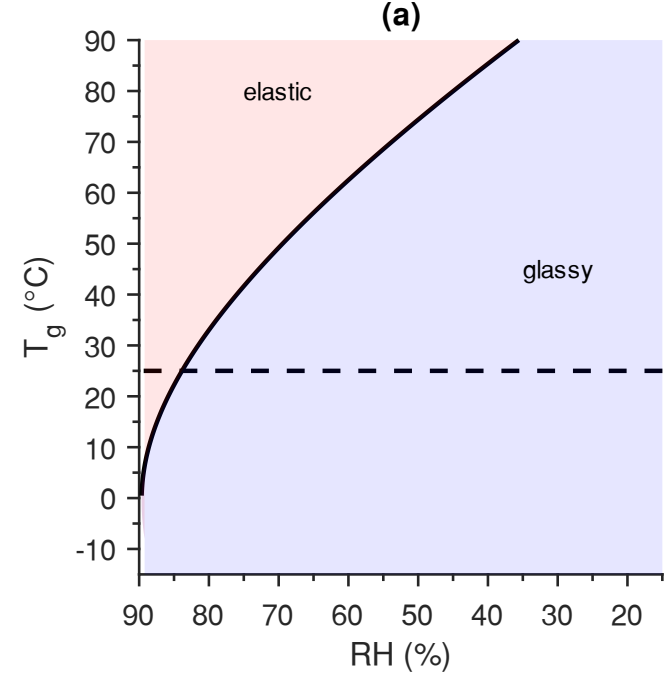

(c)

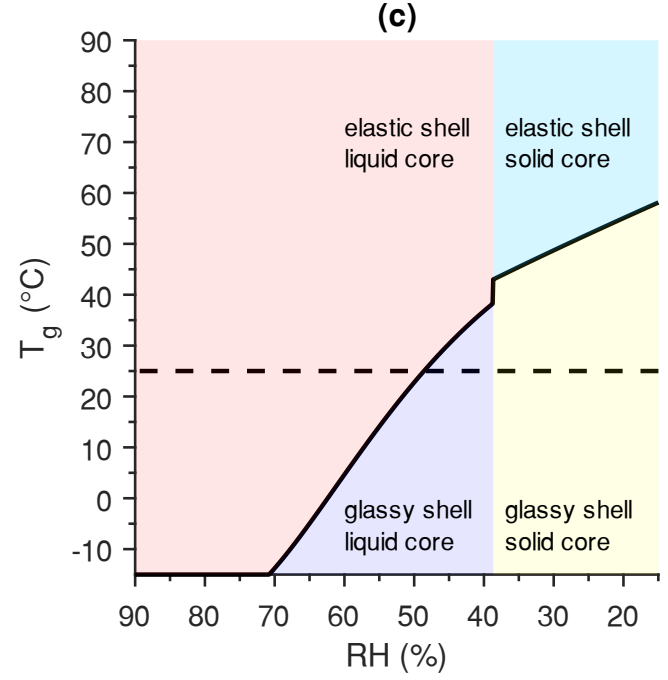

(b)

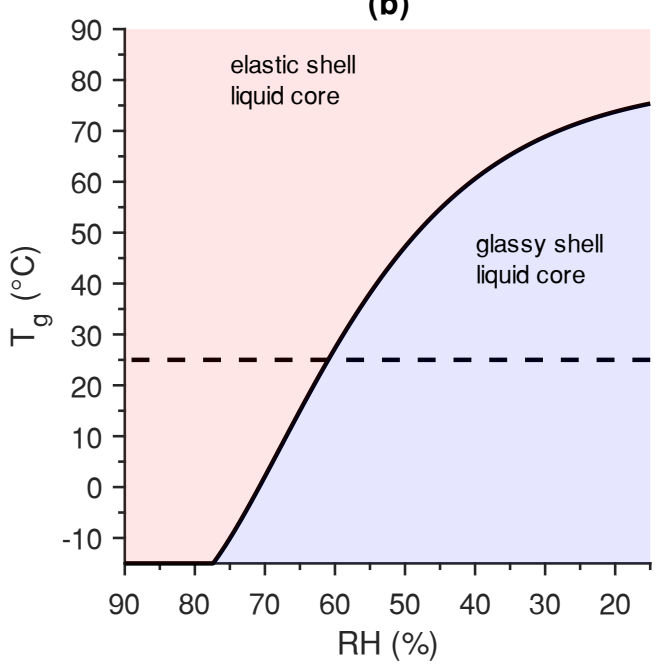

(d)

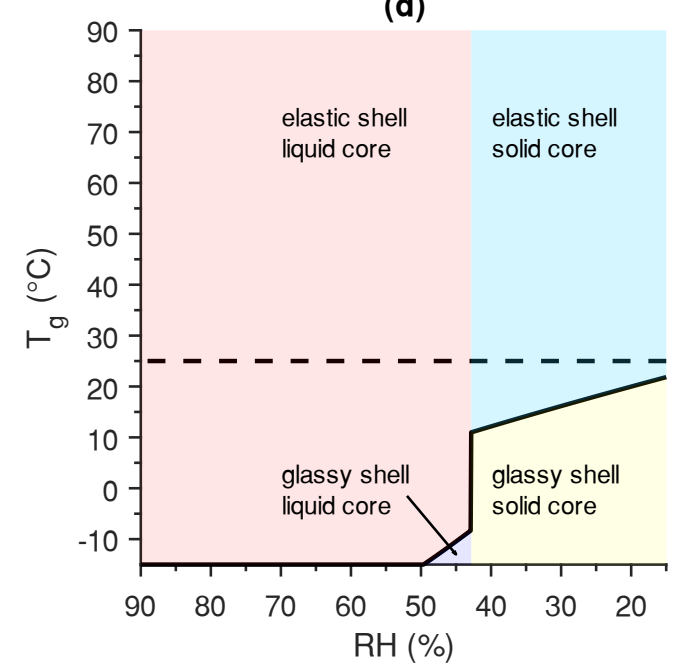

Figure 4. Predicted glass transition temperature ( $\left.T_{g}\right)$ of simulated respiratory fluid particles as a function of RH for $(a)$

In the case of the samples measured in this study, it is expected that the dynamic phase behavior of the particles would be consistent with the results reported by Huynh et al. ${ }^{29}$. Immediately at generation, the particles will be liquid droplets and through dehydration, the particles would transition from a liquid to an amorphous solid through aggregation and gelation of proteins (Figure 4, red region) ${ }^{29}$. As these particles further release water (decreasing $\mathrm{RH}$ ), the viscosity of the elastic protein 
gel will increase and eventually vitrify at sufficiently high drying rates (Figure 4, dark-blue region).

245 This process was incorporated by Dette et al. as the 'MARBLES' technique to observe glass transition in organic aerosols ${ }^{45}$. For lower organic fractions, and thus higher inorganic fractions, it becomes less probable that the particles will vitrify in room conditions due to the decreasing glass transition temperature (Figure $4 \mathrm{~d}$ ).

\subsection{Extension to airborne transmission of viruses}

In the context of airborne virus transmission, the predicted phase sate of the particles in typical ambient room conditions is most important. The dynamic transport of respiratory aerosol begins in the respiratory tract of one individual at approximately $37{ }^{\circ} \mathrm{C}$ and $100 \% \mathrm{RH}$. The final phase of transport will involve reinhalation of a particle to another individual, also at $37{ }^{\circ} \mathrm{C}$ and $100 \% \mathrm{RH}$. Between these phases, the second phase of transport is spatiotemporally dependent, and will vary between climatic and indoor conditions. From the morphology and phases discussed earlier, it is evident that typical indoor air conditions $\left(30 \%>\mathrm{RH}>60 \%, 20^{\circ} \mathrm{C}<\mathrm{T}<25^{\circ} \mathrm{C}\right)$ may be a problematic intersection of respiratory aerosol physicochemistry. During the process of respiratory aerosol transport, it is evident that the particles will experience a large temperature and $\mathrm{RH}$ differential $\left(\sim 10^{\circ} \mathrm{C}\right.$ and $\sim 50 \% \mathrm{RH}$ over $\sim 1$ second during expiration into room air). Rapid cooling and/or drying rates are typically required for glass transitions, which further suggests that glass transition of respiratory aerosols are possible 45,46 .

As discussed earlier, these respiratory particles can be classified as either efflorescing $\left(\phi_{0}<0.96\right.$, Figure $4 \mathrm{c}, \mathrm{d})$ or non-efflorescing ( $\phi_{\mathrm{O}}>0.96$, Figure $\left.4 \mathrm{a}, \mathrm{b}\right)$. Efflorescing particles below the ERH will promote the viability of viruses such as influenza A virus H3N2 and human rhinovirus-16 ${ }^{8,9}$, while having lower viability in moderate $\mathrm{RH}$ ( $\mathrm{ERH}>\mathrm{RH}>60 \%$ ). High temperature environments will favor elastic shells (Figure 4, red and light-blue regions), whereas low temperature environments will favor glassy shells (Figure 4, dark-blue and yellow regions). High RH environments will favor aqueous cores (Figure 4, red and dark-blue regions)., and low RH environments will favor crystalline cores (Figure 4, light-blue and yellow regions). If the particles are below the threshold for glass transition, then it is assumed that they will be kinetically 'frozen' at the RH at the transition boundary. Viruses in non-efflorescing particles (high $\phi_{0}$ ) will likely have higher viability in all $\mathrm{RH}$ situations due to low ion concentration (no disinfectant effect) and a protein-enriched microenvironment. Additionally, the high viscosity of low-RH non-efflorescing particles will further promote virus viability by limiting the molecular transport of oxidizing species and other harmful reactants ${ }^{29}$. Therefore, the composition of the respiratory droplets must be directly linked with the phase state and morphology and depend on the ambient conditions, especially RH and T. Further, the viability of viruses embedded within these respiratory droplets is also linked to the composition of the particles. 


\subsection{Particle morphology and force spectroscopy}

280 To confirm the morphology and phases predicted earlier (Figure 4), simulated respiratory fluid (SRF) particles were investigated using transmission electron microscopy (TEM) and atomic force microscopy (AFM). The observed morphologies could be primarily classified as: core-shell (Figure 5), embedded polycrystals (Figure 6), or ambiguous semisolid (Figure 7). The differing observed morphologies suggest that the distribution of PGM within the aerosols was not homogeneous. It is assumed that the distribution of aqueous $\mathrm{NaCl}$ is uniform due to high water solubility and thus complete dissociation within the solution. Therefore, the organic volume fraction of the droplets will be a distribution of what was measured in the bulk, indicating that the composition of each individual droplet will affect the morphology of the dried particles ${ }^{34,47}$.

(a)

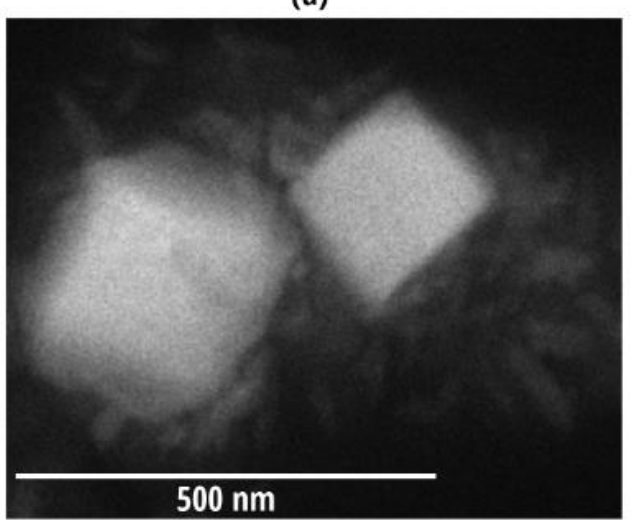

(c)

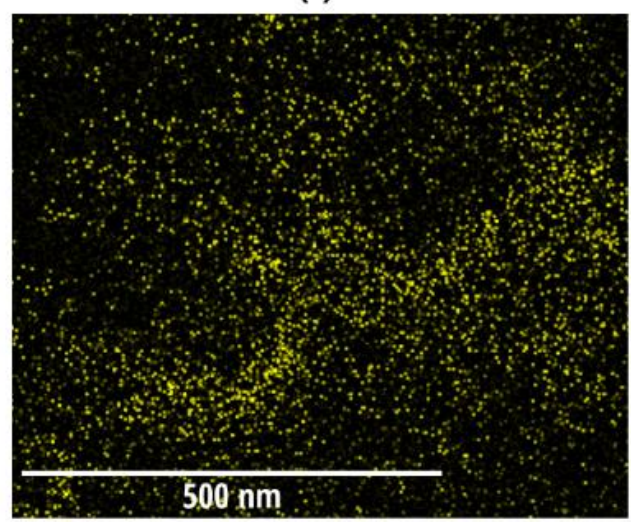

(b)

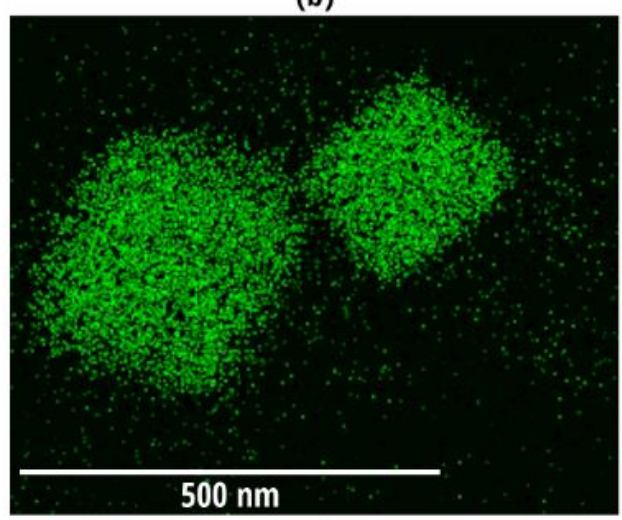

(d)

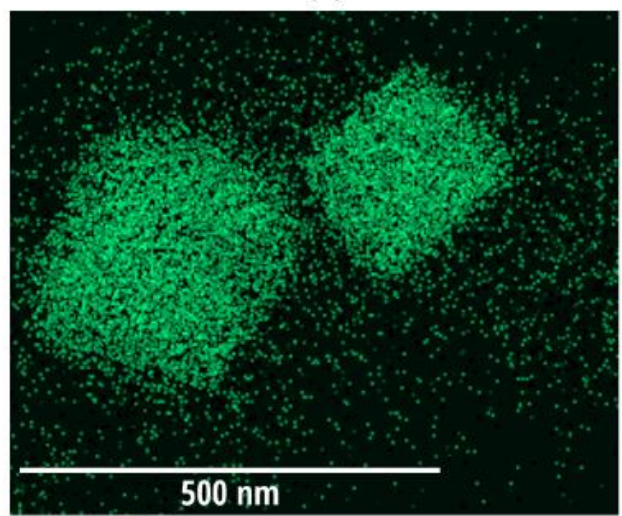

Figure 5. Energy-dispersive X-ray spectroscopy (EDS) mapped electron micrographs of a simulated respiratory fluid particle (70\% mucin by dry solute volume) deposited on a continuous carbon TEM grid. The images are (a) reference micrograph, (b) sodium EDS map, (c) oxygen EDS map and (d) chlorine EDS map.

The energy-dispersive X-ray spectroscopy (EDS) mapped images of the core-shell morphology (Figure 5) show two particles each containing single crystal of $\mathrm{NaCl}$. From the oxygen map (Figure $5 \mathrm{c}$ ), higher concentrations of oxygen are mapped to edges of the $\mathrm{NaCl}$ crystals, indicating a higher protein concentration region on the surface of the crystals ${ }^{48}$. At high RH, surface partitioned organics 
are expected through liquid-liquid phase separation (LLPS) ${ }^{49-51}$. As the particle equilibrates with low$\mathrm{RH}$ environments, especially $\mathrm{RH}<\mathrm{ERH}$, the aqueous $\mathrm{NaCl}$ will effloresce, and the resulting morphology will typically be an $\mathrm{NaCl}$ crystal covered with an organic shell ${ }^{49}$.

(a)

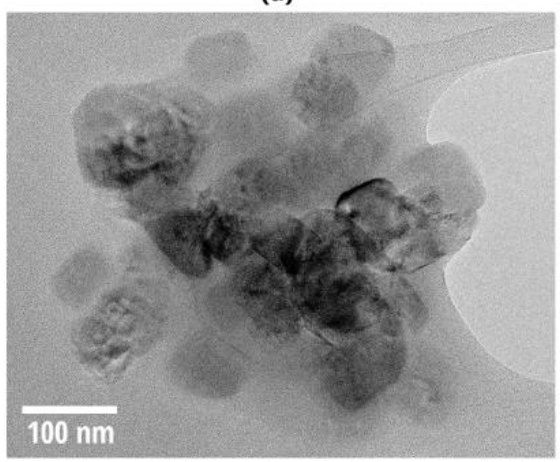

(c)

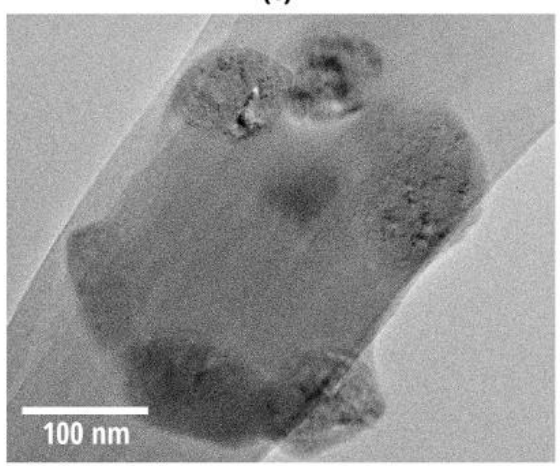

(b)

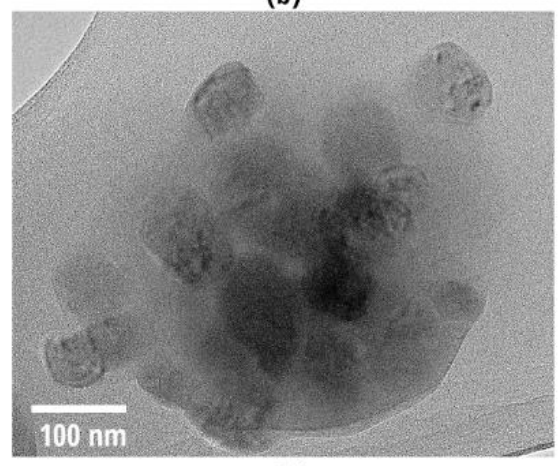

(d)

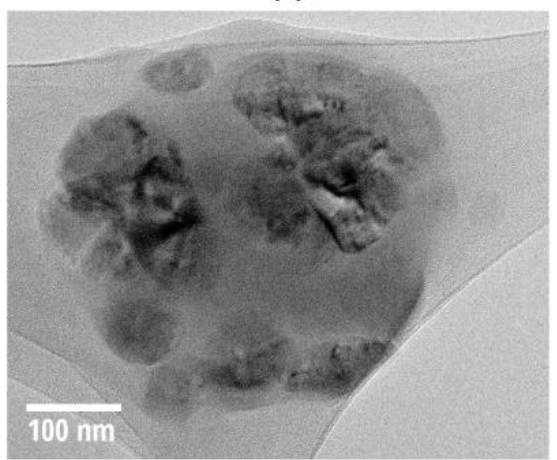

302

Figure 6. Transmission electron micrographs of simulated respiratory fluid aerosol (90\% mucin by dry solute volume) deposited on a lacey carbon grid. The micrographs display a collection of particles with multiple NaCl crystals embedded in porcine gastric mucin.

A collection of TEM micrographs showing polycrystalline $\mathrm{NaCl}$ embedded within the protein (Figure 6) shows distinct crystal formation. Higher drying rates may influence the nucleation of polycrystal structures, where upon drying, the viscosity of the organic phase increases and will kinetically limit the diffusion of water out of the particles ${ }^{52-56}$. At generation, where $\mathrm{RH} \approx 100 \%$, the particles are likely homogeneous liquid droplets. Upon dehydration, LLPS will occur between organic and inorganic phases ${ }^{57,58}$. The aqueous inorganics form multiple inclusions, and will not coalesce into a single phase before nucleation due to the inhibitive viscosity of the organic matrix, resulting in multiple crystal structures ${ }^{51,59}$. For particles with slower drying rates, or lower organic concentration, it is expected that a single aqueous $\mathrm{NaCl}$ inclusion will emerge, resulting in a core-shell morphology. 
(a)

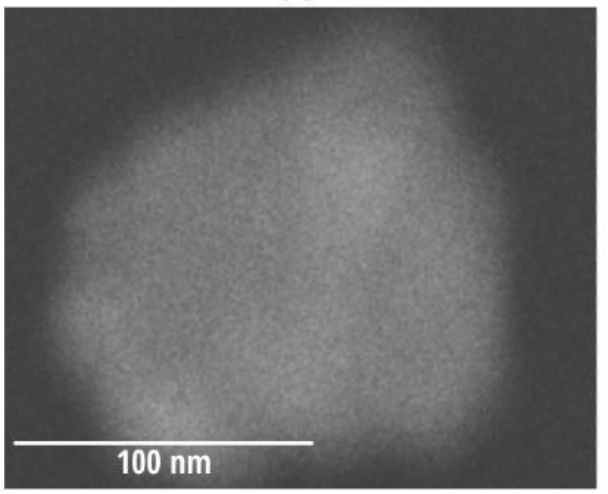

(c)

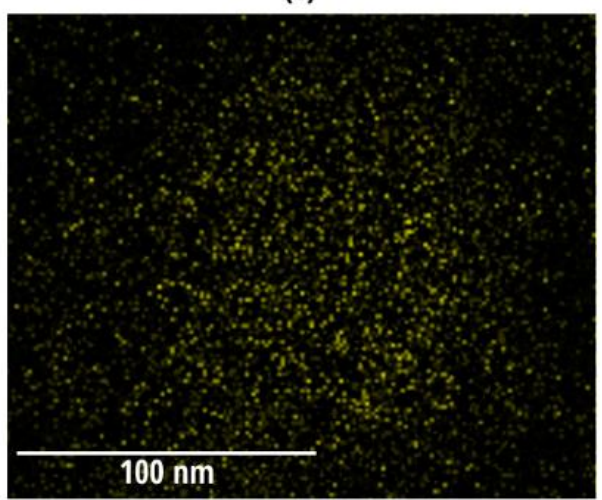

(b)

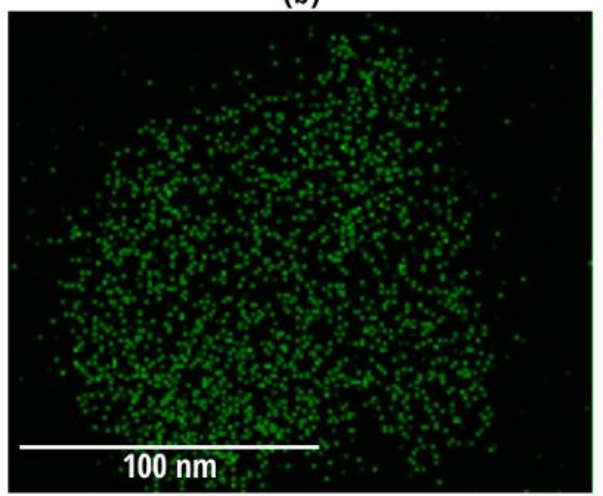

(d)

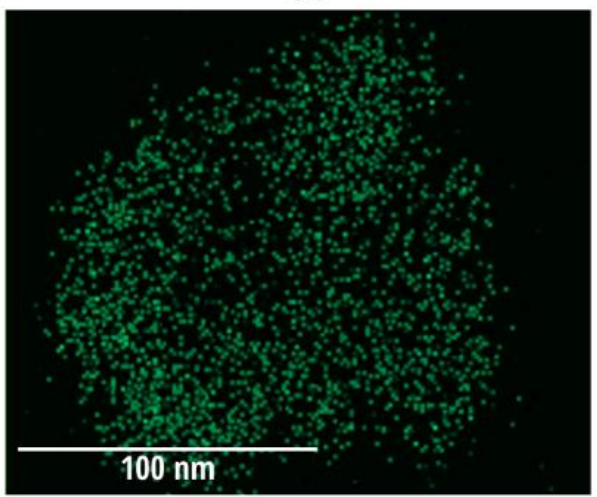

317 Figure 7. Energy-dispersive X-ray spectroscopy mapped micrographs of a simulated respiratory fluid particle (90\% mucin 318 by volume) deposited on a continuous carbon TEM grid. The images are (a) reference micrograph, (b) sodium EDS map, (c) 319 oxygen EDS map, and (d) chlorine EDS map.

320 An example of an ambiguous amorphous particle is shown in Figure 7, where the EDS spectrum

321 clearly shows the presence of sodium and chlorine distribution homogeneously thoroughly the particle 322 with no clear crystal structure. This particle morphology may be cause by sufficiently high viscosity 323 which completely prevents efflorescence of the salts, or perhaps through aqueous $\mathrm{NaCl}$ diffusing into 324 the cells of the PGM through osmosis and being kinetically 'frozen' in. 

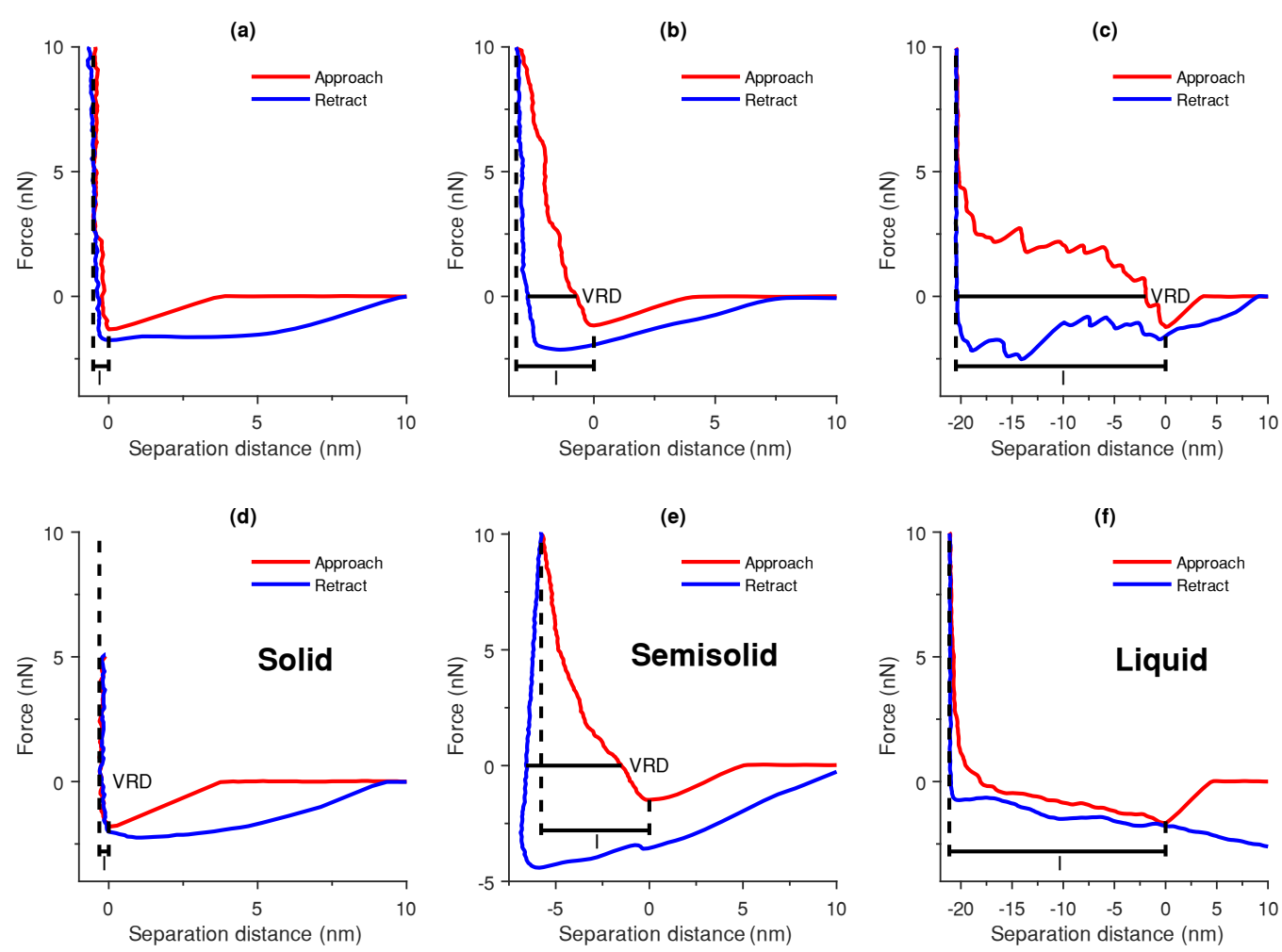

Figure 8. Representative force response curves for pure porcine gastric mucin particles (height $=68 \mathrm{~nm}, 80 \mathrm{~nm}, 78 \mathrm{~nm}$, respectively) deposited on a Si chip at a maximum applied force of $10 \mathrm{nN}$ at $35 \% \mathrm{RH}$. The determination of indentation depth (I) and viscoelastic response distance (VRD) are shown graphically. The top three figures represent the behavior of (a) solid, (b) highly-viscous semisolid, and (c) moderately-viscous semisolid mucin particles. Shown also are representative force response curves for (d) $\mathrm{NaCl}$ (solid), (e) sucrose (semisolid), and (f) malonic acid (liquid).

The viscoelastic response distance (VRD) and relative indentation depth (RID) of pure PGM particles $(\mathrm{N}=103)$ were measured through AFM force spectroscopy at 35\% RH. In each force response measurement, the tip is indented into the particle until the force threshold $(10 \mathrm{nN})$ is reached. The RID is calculated as the ratio of the indentation depth and the height of the particle. For solid particles, the RID is expected to be low because the tip cannot indent a large distance into the particles, and for liquid particles the RID should be approximately 1 . The VRD is measured through hysteresis in the force response measurements (at force $=0$ ) due to viscoelastic properties of the material. The results presented by Lee et al. and Ray et al. suggest that particles with VRD $<0.5 \mathrm{~nm}$ are solid and with VRD $>0.5 \mathrm{~nm}$ are viscoelastic semisolids ${ }^{41,42}$. Additionally, the largest mean VRD reported by Ray et al. was $\sim 2.5 \mathrm{~nm}$, suggesting that particles with VRD $>2.5 \mathrm{~nm}$ are likely less viscous semisolids. From the 103 particles measured using force spectroscopy in this study, $30 \%$ had VRD $<0.5 \mathrm{~nm}$ (solid, Figure 8a), 20\% had $0.5 \mathrm{~nm}<\mathrm{VRD}<2.5 \mathrm{~nm}$ (highly-viscous semisolid, Figure 8b), and $\sim 50 \%$ had VRD $>2.5 \mathrm{~nm}$ (moderately-viscous semisolid, Figure 8c). The average aspect ratio of the particles measured here was $0.50 \pm 0.17$ (Figure S5b). Representative force response curves were collected for representative solid ( $\mathrm{NaCl}$, Figure 8d), semisolid (sucrose, Figure 8e) and liquid 
346 (malonic acid, Figure 8f). The $\mathrm{NaCl}$ and sucrose force response curves shown here (Figure 8d,e) agree 347 with previously reported results ${ }^{41,42}$. This potentially provides a lower bound on the viscosity of the 348 dried PGM particles at $10^{6} \mathrm{~Pa} \cdot \mathrm{s}^{41}$.

\section{Conclusions}

In this study, we constructed simulated respiratory fluid using porcine gastric mucin (PGM) and $\mathrm{NaCl}$ mixed in known ratios. The systems investigated here show comparative behavior to that of human respiratory aerosol. Specifically, efflorescence and deliquescence are observed at similar relative humidity (RH) with similar hygroscopic growth factors at 90\% RH. Efflorescence was observed in most cases, however, 96\% PGM by dry solute volume appears to be the threshold between efflorescing and non-efflorescing particles. The hygroscopicity measured in this study were used retroactively to estimate the organic volume fraction of dry solutes $\left(\phi_{0}\right)$ of human respiratory aerosol as measured in our previous study ${ }^{20}$. In both human respiratory aerosol (prior study) and simulated respiratory aerosol (this work), all efflorescing systems corresponded to $\phi_{0}<0.96$.

Transmission electron microscopy (TEM), energy-dispersive X-ray spectroscopy (EDS), and atomic force microscopy (AFM) were used to investigate the morphology of dried particles. Four morphologies were observed, three of which had crystalline $\mathrm{NaCl}$ and one which did not crystallise but still contained sodium and chlorine. Further, this cannot be an aqueous $\mathrm{NaCl}$ phase because a TEM operates at vacuum and the droplets will contain no liquid water. One hypothesis for this phenomenon, of ambiguous $\mathrm{NaCl}$ observed in a dry particle, is that aqueous $\mathrm{NaCl}$ diffuses into the protein cells through osmosis, and due to the high viscosity of the amorphous protein, the $\mathrm{NaCl}$ becomes kinetically 'frozen in'. The distribution of these phases is likely dependent on the drying rate of the particles.

Direct measurements of glass transition in PGM in prior works were adapted to predict the glass transition temperature $\left(\mathrm{T}_{\mathrm{g}}\right.$ ) of PGM aerosols. Then, the efflorescence of ternary PGM/NaCl/water droplets were incorporated into the phase diagram to more completely predict the phase state of the particles at different equilibria. It is predicted that high $\phi_{0}$ particles will more readily vitrify in room conditions, and low $\phi_{\mathrm{O}}$ particles will preferentially crystallise and form a core-shell morphology. A polycrystalline morphology was observed and may be an implicit indication of liquid-liquid phase separation (LLPS) in respiratory particles. The behavior of these systems can then be used to investigate the microenvironment in which viruses will exist during airborne transport. The viscoelastic response of dried PGM aerosols was measured using AFM (N=103) and it was determined that $\sim 50 \%$ of the particles were in a solid or highly-viscous semisolid state, and the remaining $\sim 50 \%$ were in a moderately-viscous semisolid state. 
Any case in which efflorescence occurs (high inorganic fraction, slow drying, RH<ERH) are expected to be favorable to virus survival due to limited exposure to concentrated aqueous salts. At RH>ERH, the salts will be in an aqueous phase, and the protein will either be in a gel or glassy phase. Gel-liquid core-shell morphologies are expected to be unfavorable for virus viability due to the aqueous inorganic phase. Conversely, glassy-liquid core-shell morphologies may be favorable for virus viability. Upon drying below $\mathrm{T}_{\mathrm{g}}$, the organic phase becomes viscous and limits kinetic processes within the particle, including water diffusion. This delays equilibration and the particle can remain in this metastable state for extended periods. Therefore, it is possible that a glassy organic shell may 'freeze' the particle in a state with a relatively dilute aqueous core. The viscosity of the organic matrix may also limit diffusion of disinfectants or oxidants into the particles.

Although lacking the complexity of real respiratory fluid, the results of this study expand on prior physicochemical characterisation of simulated respiratory fluid ${ }^{8,29,31,32}$. Future investigations involving increasingly representative compositions may be useful (e.g., the inclusion of surfactants and different inorganics, or animal respiratory fluid), although it is unlikely that completely simulating the complexity of both the composition and production mechanisms of respiratory aerosol is possible.

\section{Authors' Contributions}

All authors contributed to experimental design. R.G., S.N., and G.R.J. contributed to experimentation. R.G. and Z.R. contributed to data analysis and interpretation. All authors contributed to the manuscript drafting and revision.

\section{Competing Interests}

The authors declare no competing interests.

\section{Funding}

This study was funded by the Australian Research Council discovery grant no. DP210103284.

\section{Acknowledgments}

We acknowledge the important role of the Central Analytical Research Facility (CARF) in maintaining, facilitating the use of, and training users on the analytical instruments used in this study, namely a JEOL 2100 TEM and a Bruker Icon Dimension PT AFM.

\section{References}

(1) Asadi, S.; Wexler, A. S.; Cappa, C. D.; Barreda, S.; Bouvier, N. M.; Ristenpart, W. D. Aerosol Emission and Superemission during Human Speech Increase with Voice Loudness. Scientific Reports 2019, 9 (1), 2348. https://doi.org/10.1038/s41598-019-38808-z. 
(2) Lindsley, W. G.; Blachere, F. M.; Beezhold, D. H.; Thewlis, R. E.; Noorbakhsh, B.; Othumpangat, S.; Goldsmith, W. T.; McMillen, C. M.; Andrew, M. E.; Burrell, C. N.; Noti, J. D. Viable Influenza A Virus in Airborne Particles Expelled during Coughs versus Exhalations. Influenza Other Respi Viruses 2016, 10 (5), 404-413. https://doi.org/10.1111/irv.12390.

(3) Morawska, L.; Milton, D. K. It Is Time to Address Airborne Transmission of Coronavirus Disease 2019 (COVID-19). Clinical Infectious Diseases 2020, ciaa939. https://doi.org/10.1093/cid/ciaa939.

(4) Morawska, L.; Cao, J. Airborne Transmission of SARS-CoV-2: The World Should Face the Reality. Environment International 2020, 139, 105730. https://doi.org/10.1016/j.envint.2020.105730.

(5) Greenhalgh, T.; Jimenez, J. L.; Prather, K. A.; Tufekci, Z.; Fisman, D.; Schooley, R. Ten Scientific Reasons in Support of Airborne Transmission of SARS-CoV-2. The Lancet 2021, 397 (10285), 1603-1605. https://doi.org/10.1016/S0140-6736(21)00869-2.

(6) Yang, W.; Marr, L. C. Dynamics of Airborne Influenza A Viruses Indoors and Dependence on Humidity. PLoS One 2011, 6 (6), e21481. https://doi.org/10.1371/journal.pone.0021481.

(7) Yang, W.; Elankumaran, S.; Marr, L. C. Relationship between Humidity and Influenza A Viability in Droplets and Implications for Influenza's Seasonality. PLOS ONE 2012, 7 (10), e46789. https://doi.org/10.1371/journal.pone.0046789.

(8) Niazi, S.; Groth, R.; Cravigan, L.; He, C.; Tang, J. W.; Spann, K.; Johnson, G. R. Susceptibility of an Airborne Common Cold Virus to Relative Humidity. Environ. Sci. Technol. 2021, 55 (1), 499508. https://doi.org/10.1021/acs.est.0c06197.

(9) Niazi, S.; Short, K. R.; Groth, R.; Cravigan, L.; Spann, K.; Ristovski, Z.; Johnson, G. R. HumidityDependent Survival of an Airborne Influenza A Virus: Practical Implications for Controlling Airborne Viruses. Environ. Sci. Technol. Lett. 2021, 8 (5), 412-418. https://doi.org/10.1021/acs.estlett.1c00253.

(10) Shaman, J.; Kohn, M. Absolute Humidity Modulates Influenza Survival, Transmission, and Seasonality. Proceedings of the National Academy of Sciences 2009, 106 (9), 3243-3248. https://doi.org/10.1073/pnas.0806852106.

(11) Tamerius, J. D.; Shaman, J.; Alonso, W. J.; Bloom-Feshbach, K.; Uejio, C. K.; Comrie, A.; Viboud, C. Environmental Predictors of Seasonal Influenza Epidemics across Temperate and Tropical Climates. PLoS Pathogens 2013, 9 (3), e1003194. https://doi.org/10.1371/journal.ppat.1003194.

(12) Tang, J. W. The Effect of Environmental Parameters on the Survival of Airborne Infectious Agents. Journal of The Royal Society Interface 2009, 6 (suppl_6). https://doi.org/10.1098/rsif.2009.0227.focus.

(13) Niazi, S.; Groth, R.; Spann, K.; Johnson, G. R. The Role of Respiratory Droplet Physicochemistry in Limiting and Promoting the Airborne Transmission of Human Coronaviruses: A Critical Review. Environmental Pollution 2020, 115767. https://doi.org/10.1016/j.envpol.2020.115767.

(14) Johnson, G. R.; Morawska, L. The Mechanism of Breath Aerosol Formation. Journal of Aerosol Medicine and Pulmonary Drug Delivery 2009, 22 (3), 229-237. https://doi.org/10.1089/jamp.2008.0720.

(15) Johnson, G. R.; Morawska, L.; Ristovski, Z. D.; Hargreaves, M.; Mengersen, K.; Chao, C. Y. H.; Wan, M. P.; Li, Y.; Xie, X.; Katoshevski, D.; Corbett, S. Modality of Human Expired Aerosol Size Distributions. Journal of Aerosol Science 2011, 42 (12), 839-851. https://doi.org/10.1016/j.jaerosci.2011.07.009.

(16) Morawska, L.; Johnson, G. R.; Ristovski, Z. D.; Hargreaves, M.; Mengersen, K.; Corbett, S.; Chao, C. Y. H.; Li, Y.; Katoshevski, D. Size Distribution and Sites of Origin of Droplets Expelled from the Human Respiratory Tract during Expiratory Activities. Journal of Aerosol Science 2009, 40 (3), 256-269. https://doi.org/10.1016/j.jaerosci.2008.11.002. 
(17) Fahy, J. V.; Dickey, B. F. Airway Mucus Function and Dysfunction. The New England Journal of Medicine 2010, 363 (23), 2233-2247. https://doi.org/10.1056/NEJMra0910061.

(18) Thornton, D. J.; Rousseau, K.; McGuckin, M. A. Structure and Function of the Polymeric Mucins in Airways Mucus. Annu. Rev. Physiol. 2008, 70 (1), 459-486. https://doi.org/10.1146/annurev.physiol.70.113006.100702.

(19) Boisa, N.; Elom, N.; Dean, J. R.; Deary, M. E.; Bird, G.; Entwistle, J. A. Development and Application of an Inhalation Bioaccessibility Method (IBM) for Lead in the PM10 Size Fraction of Soil. Environment International 2014, 70, 132-142. https://doi.org/10.1016/j.envint.2014.05.021.

(20) Groth, R.; Cravigan, L. T.; Niazi, S.; Ristovski, Z.; Johnson, G. R. In Situ Measurements of Human Cough Aerosol Hygroscopicity. Journal of The Royal Society Interface 2021, 18 (178), 9.

(21) Kormuth, K. A.; Lin, K.; Prussin, A. J.; Vejerano, E. P.; Tiwari, A. J.; Cox, S. S.; Myerburg, M. M.; Lakdawala, S. S.; Marr, L. C. Influenza Virus Infectivity Is Retained in Aerosols and Droplets Independent of Relative Humidity. The Journal of Infectious Diseases 2018, 218 (5), 739-747. https://doi.org/10.1093/infdis/jiy221.

(22) Morris, D. H.; Yinda, K. C.; Gamble, A.; Rossine, F. W.; Huang, Q.; Bushmaker, T.; Fischer, R. J.; Matson, M. J.; Van Doremalen, N.; Vikesland, P. J.; Marr, L. C.; Munster, V. J.; Lloyd-Smith, J. $\mathrm{O}$. Mechanistic Theory Predicts the Effects of Temperature and Humidity on Inactivation of SARS-CoV-2 and Other Enveloped Viruses. eLife 2021, 10, e65902. https://doi.org/10.7554/eLife.65902.

(23) Prussin, A. J.; Schwake, D. O.; Lin, K.; Gallagher, D. L.; Buttling, L.; Marr, L. C. Survival of the Enveloped Virus Phi6 in Droplets as a Function of Relative Humidity, Absolute Humidity, and Temperature. Applied and Environmental Microbiology 2018, 84 (12), e00551-18, /aem/84/12/e00551-18.atom. https://doi.org/10.1128/AEM.00551-18.

(24) Lin, K.; Schulte, C. R.; Marr, L. C. Survival of MS2 and $\Phi 6$ Viruses in Droplets as a Function of Relative Humidity, PH, and Salt, Protein, and Surfactant Concentrations. PLOS ONE 2020, 15 (12), e0243505. https://doi.org/10.1371/journal.pone.0243505.

(25) Pan, M.; Carol, L.; Lednicky, J. A.; Eiguren-Fernandez, A.; Hering, S.; Fan, Z. H.; Wu, C.-Y. Determination of the Distribution of Infectious Viruses in Aerosol Particles Using Water-Based Condensational Growth Technology and a Bacteriophage MS2 Model. Aerosol Science and Technology 2019, 1-11. https://doi.org/10.1080/02786826.2019.1581917.

(26) Shiraiwa, M.; Ammann, M.; Koop, T.; Poschl, U. Gas Uptake and Chemical Aging of Semisolid Organic Aerosol Particles. Proceedings of the National Academy of Sciences 2011, 108 (27), 11003-11008. https://doi.org/10.1073/pnas.1103045108.

(27) Shiraiwa, M.; Li, Y.; Tsimpidi, A. P.; Karydis, V. A.; Berkemeier, T.; Pandis, S. N.; Lelieveld, J.; Koop, T.; Pöschl, U. Global Distribution of Particle Phase State in Atmospheric Secondary Organic Aerosols. Nature Communications 2017, 8, 15002. https://doi.org/10.1038/ncomms15002.

(28) Virtanen, A.; Joutsensaari, J.; Koop, T.; Kannosto, J.; Yli-Pirilä, P.; Leskinen, J.; Mäkelä, J. M.; Holopainen, J. K.; Pöschl, U.; Kulmala, M.; Worsnop, D. R.; Laaksonen, A. An Amorphous Solid State of Biogenic Secondary Organic Aerosol Particles. Nature 2010, 467 (7317), 824-827. https://doi.org/10.1038/nature09455.

(29) Huynh, E.; Olinger, A.; Woolley, D.; Kohli, R. K.; Choczynski, J. M.; Davies, J. F.; Lin, K.; Marr, L. C.; Davis, R. D. Evidence for a Semisolid Phase State of Aerosols and Droplets Relevant to the Airborne and Surface Survival of Pathogens. Proc Natl Acad Sci USA 2022, 119 (4), e2109750119. https://doi.org/10.1073/pnas.2109750119.

(30) Walker, J. S.; Archer, J.; Gregson, F. K. A.; Michel, S. E. S.; Bzdek, B. R.; Reid, J. P. Accurate Representations of the Microphysical Processes Occurring during the Transport of Exhaled Aerosols and Droplets. ACS Cent. Sci. 2021, 7 (1), 200-209. https://doi.org/10.1021/acscentsci.0c01522. 
(31) Vejerano, E. P.; Marr, L. C. Physico-Chemical Characteristics of Evaporating Respiratory Fluid Droplets. Journal of The Royal Society Interface 2018, 15 (139), 20170939.

https://doi.org/10.1098/rsif.2017.0939.

(32) Davies, J. F.; Price, C. L.; Choczynski, J.; Kohli, R. K. Hygroscopic Growth of Simulated Lung Fluid Aerosol Particles under Ambient Environmental Conditions. Chem. Commun. 2021, 10.1039.D1CC00066G. https://doi.org/10.1039/D1CC00066G.

(33) Johnson, G. R.; Fletcher, C.; Meyer, N.; Modini, R.; Ristovski, Z. D. A Robust, Portable H-TDMA for Field Use. Journal of Aerosol Science 2008, 39 (10), 850-861.

https://doi.org/10.1016/j.jaerosci.2008.05.005.

(34) Cravigan, L. T.; Mallet, M. D.; Vaattovaara, P.; Harvey, M. J.; Law, C. S.; Modini, R. L.; Russell, L. M.; Stelcer, E.; Cohen, D. D.; Olsen, G.; Safi, K.; Burrell, T. J.; Ristovski, Z. Sea Spray Aerosol Organic Enrichment, Water Uptake and Surface Tension Effects. Atmos. Chem. Phys. 2020, 20 (13), 7955-7977. https://doi.org/10.5194/acp-20-7955-2020.

(35) Johnson, G. R. Hygroscopic Behavior of Partially Volatilized Coastal Marine Aerosols Using the Volatilization and Humidification Tandem Differential Mobility Analyzer Technique. J. Geophys. Res. 2005, 110 (D20), D20203. https://doi.org/10.1029/2004JD005657.

(36) Znamenskaya, Y.; Sotres, J.; Engblom, J.; Arnebrant, T.; Kocherbitov, V. Effect of Hydration on Structural and Thermodynamic Properties of Pig Gastric and Bovine Submaxillary Gland Mucins. The Journal of Physical Chemistry B 2012, 116 (16), 5047-5055. https://doi.org/10.1021/jp212495t.

(37) Rose, M. C.; Voynow, J. A. Respiratory Tract Mucin Genes and Mucin Glycoproteins in Health and Disease. Physiological Reviews 2006, 86 (1), 245-278. https://doi.org/10.1152/physrev.00010.2005.

(38) Wagner, C. E.; Turner, B. S.; Rubinstein, M.; McKinley, G. H.; Ribbeck, K. A Rheological Study of the Association and Dynamics of MUC5AC Gels. Biomacromolecules 2017, 18 (11), 36543664. https://doi.org/10.1021/acs.biomac.7b00809.

(39) Duplissy, J.; Gysel, M.; Sjogren, S.; Meyer, N.; Good, N.; Kammermann, L.; Michaud, V.; Weigel, R.; Martins dos Santos, S.; Gruening, C.; Villani, P.; Laj, P.; Sellegri, K.; Metzger, A.; McFiggans, G. B.; Wehrle, G.; Richter, R.; Dommen, J.; Ristovski, Z.; Baltensperger, U.; Weingartner, E. Intercomparison Study of Six HTDMAs: Results and Recommendations. Atmos. Meas. Tech. 2009, 2 (2), 363-378. https://doi.org/10.5194/amt-2-363-2009.

(40) Gysel, M.; McFiggans, G. B.; Coe, H. Inversion of Tandem Differential Mobility Analyser (TDMA) Measurements. Journal of Aerosol Science 2009, 40 (2), 134-151. https://doi.org/10.1016/j.jaerosci.2008.07.013.

(41) Lee, H. D.; Ray, K. K.; Tivanski, A. V. Solid, Semisolid, and Liquid Phase States of Individual Submicrometer Particles Directly Probed Using Atomic Force Microscopy. Anal. Chem. 2017, 89 (23), 12720-12726. https://doi.org/10.1021/acs.analchem.7b02755.

(42) Ray, K. K.; Lee, H. D.; Gutierrez, M. A.; Chang, F. J.; Tivanski, A. V. Correlating 3D Morphology, Phase State, and Viscoelastic Properties of Individual Substrate-Deposited Particles. Anal. Chem. 2019, 91 (12), 7621-7630. https://doi.org/10.1021/acs.analchem.9b00333.

(43) Mikhailov, E.; Vlasenko, S.; Niessner, R.; Poschl, U. Interaction of Aerosol Particles Composed of Protein and Salts with Water Vapor: Hygroscopic Growth and Microstructural Rearrangement. Atmospheric Chemistry and Physics 2004, 4 (2), 323-350.

(44) Stokes, R. H.; Robinson, R. A. Interactions in Aqueous Nonelectrolyte Solutions. I. SoluteSolvent Equilibria. The Journal of Physical Chemistry 1966, 70 (7), 2126-2131. https://doi.org/10.1021/j100879a010.

(45) Dette, H. P.; Qi, M.; Schröder, D. C.; Godt, A.; Koop, T. Glass-Forming Properties of 3Methylbutane-1,2,3-Tricarboxylic Acid and Its Mixtures with Water and Pinonic Acid. The Journal of Physical Chemistry A 2014, 118 (34), 7024-7033. https://doi.org/10.1021/jp505910w. 
(46) Dette, H. P.; Koop, T. Glass Formation Processes in Mixed Inorganic/Organic Aerosol Particles. The Journal of Physical Chemistry A 2015, 119 (19), 4552-4561.

https://doi.org/10.1021/jp5106967.

(47) Quinn, P. K.; Bates, T. S.; Schulz, K. S.; Coffman, D. J.; Frossard, A. A.; Russell, L. M.; Keene, W. C.; Kieber, D. J. Contribution of Sea Surface Carbon Pool to Organic Matter Enrichment in Sea Spray Aerosol. Nature Geoscience 2014, 7, 5.

(48) Ault, A. P.; Moffet, R. C.; Baltrusaitis, J.; Collins, D. B.; Ruppel, M. J.; Cuadra-Rodriguez, L. A.; Zhao, D.; Guasco, T. L.; Ebben, C. J.; Geiger, F. M.; Bertram, T. H.; Prather, K. A.; Grassian, V. H. Size-Dependent Changes in Sea Spray Aerosol Composition and Properties with Different Seawater Conditions. Environmental Science \& Technology 2013, 47 (11), 5603-5612. https://doi.org/10.1021/es400416g.

(49) Lee, H. D.; Wigley, S.; Lee, C.; Or, V. W.; Hasenecz, E. S.; Stone, E. A.; Grassian, V. H.; Prather, K. A.; Tivanski, A. V. Physicochemical Mixing State of Sea Spray Aerosols: Morphologies Exhibit Size Dependence. ACS Earth Space Chem. 2020, 4 (9), 1604-1611. https://doi.org/10.1021/acsearthspacechem.0c00153.

(50) Karadima, K. S.; Mavrantzas, V. G.; Pandis, S. N. Insights into the Morphology of Multicomponent Organic and Inorganic Aerosols from Molecular Dynamics Simulations. Atmospheric Chemistry and Physics 2019, 19 (8), 5571-5587. https://doi.org/10.5194/acp-195571-2019.

(51) Fard, M. M.; Krieger, U. K.; Peter, T. Kinetic Limitation to Inorganic Ion Diffusivity and to Coalescence of Inorganic Inclusions in Viscous Liquid-Liquid Phase-Separated Particles. J. Phys. Chem. A 2017, 121 (48), 9284-9296. https://doi.org/10.1021/acs.jpca.7b05242.

(52) Zobrist, B.; Soonsin, V.; Luo, B. P.; Krieger, U. K.; Marcolli, C.; Peter, T.; Koop, T. Ultra-Slow Water Diffusion in Aqueous Sucrose Glasses. Physical Chemistry Chemical Physics 2011, 13 (8), 3514. https://doi.org/10.1039/c0cp01273d.

(53) Bones, D. L.; Reid, J. P.; Lienhard, D. M.; Krieger, U. K. Comparing the Mechanism of Water Condensation and Evaporation in Glassy Aerosol. Proceedings of the National Academy of Sciences 2012, 109 (29), 11613-11618. https://doi.org/10.1073/pnas.1200691109.

(54) Freedman, M. A. Phase Separation in Organic Aerosol. Chemical Society Reviews 2017, 46 (24), 7694-7705. https://doi.org/10.1039/C6CS00783J.

(55) Berkemeier, T.; Shiraiwa, M.; Pöschl, U.; Koop, T. Competition between Water Uptake and Ice Nucleation by Glassy Organic Aerosol Particles. Atmospheric Chemistry and Physics 2014, 14 (22), 12513-12531. https://doi.org/10.5194/acp-14-12513-2014.

(56) Lu, J. W.; Rickards, A. M. J.; Walker, J. S.; Knox, K. J.; Miles, R. E. H.; Reid, J. P.; Signorell, R. Timescales of Water Transport in Viscous Aerosol: Measurements on Sub-Micron Particles and Dependence on Conditioning History. Phys. Chem. Chem. Phys. 2014, 16 (21), 9819-9830. https://doi.org/10.1039/C3CP54233E.

(57) Song, M.; Ham, S.; Andrews, R. J.; You, Y.; Bertram, A. K. Liquid-Liquid Phase Separation in Organic Particles Containing One and Two Organic Species: Importance of the Average O:C. Atmos. Chem. Phys. 2018, 18 (16), 12075-12084. https://doi.org/10.5194/acp-18-120752018.

(58) Song, M.; Marcolli, C.; Krieger, U. K.; Zuend, A.; Peter, T. Liquid-Liquid Phase Separation and Morphology of Internally Mixed Dicarboxylic Acids/Ammonium Sulfate/Water Particles. Atmospheric Chemistry and Physics 2012, 12 (5), 2691-2712. https://doi.org/10.5194/acp-122691-2012.

(59) Ma, S.; Chen, Z.; Pang, S.; Zhang, Y. Observations on Hygroscopic Growth and Phase Transitions of Mixed 1, 2, 6-Hexanetriol / (NH4)2SO4 Particles: Investigation of the LiquidLiquid Phase Separation (LLPS) Dynamic Process and Mechanism and Secondary LLPS during the Dehumidification. Atmos. Chem. Phys. 2021, 21 (12), 9705-9717.

https://doi.org/10.5194/acp-21-9705-2021. 